\title{
Synthesis of a family of Pt-Ag clusters: Ligands, solvents, unit cells and crystal quality
}

Milagros Tomás, Irene Ara, M. Angeles García-Monforte, Rocío González and L. R. Falvello

University of Zaragoza - CSIC, Department of Inorganic Chemistry, Institute for Chemical Synthesis and Homogeneous Catalysis, Aragón Materials Science Institute, Pedro Cerbuna 12, 50009 Zaragoza, Spain

milagros@unizar.es

The characteristic coordination indices of $\mathrm{Pt}^{\mathrm{II}}$ and $\mathrm{Pt}^{\mathrm{IV}}$ are combined with novel $(\mathrm{OH})$ bridging systems to form a mixed-oxidation-state Pt cluster with a structurally unprecedented $\mathrm{M}_{4}(\mathrm{OH})_{4}$ core. The anion in $\left(\mathrm{NBu}_{4}\right)_{2}\left[\mathrm{Pt}^{\mathrm{IV}} \mathrm{Pt}_{3}{ }_{3}\left(\mathrm{C}_{6} \mathrm{Cl}_{5}\right)_{8}\left(\mu_{2}-\mathrm{OH}\right)_{2}\left(\mu_{3}-\mathrm{OH}\right)_{2}\right]$ (1) has two $\left(\mu_{3}-\mathrm{OH}\right)$ and two $\left(\mu_{2}-\mathrm{OH}\right)$ units that bridge platinum atoms in different oxidation states. The geometry at the core of the cluster is described as a distorted halfhexagram. Compound (1) can host full-shell $\mathrm{d}^{10}$ or $\mathrm{s}^{2}$ Lewis-acid metals, which are held in place by $\mathrm{Pt} \rightarrow \mathrm{M}$ dative bonds. The syntheses of several solids, some of them with unbridged $\mathrm{Pt} \rightarrow \mathrm{Ag}$ bonds, without disrupting the fundamental core geometry of the anion (1), accredits the host potential of (1). Interesting relationships arise among ligands, solvents, unit cells and crystal quality. The role of weak $\mathrm{C}-\mathrm{Cl} \cdots \mathrm{Ag}$ interactions in stabilizing these compounds is also described. 